International Centre for Integrated

Mountain Development

\title{
MINI- AND MICRO-HYDROPOWER IN NEPAL
}

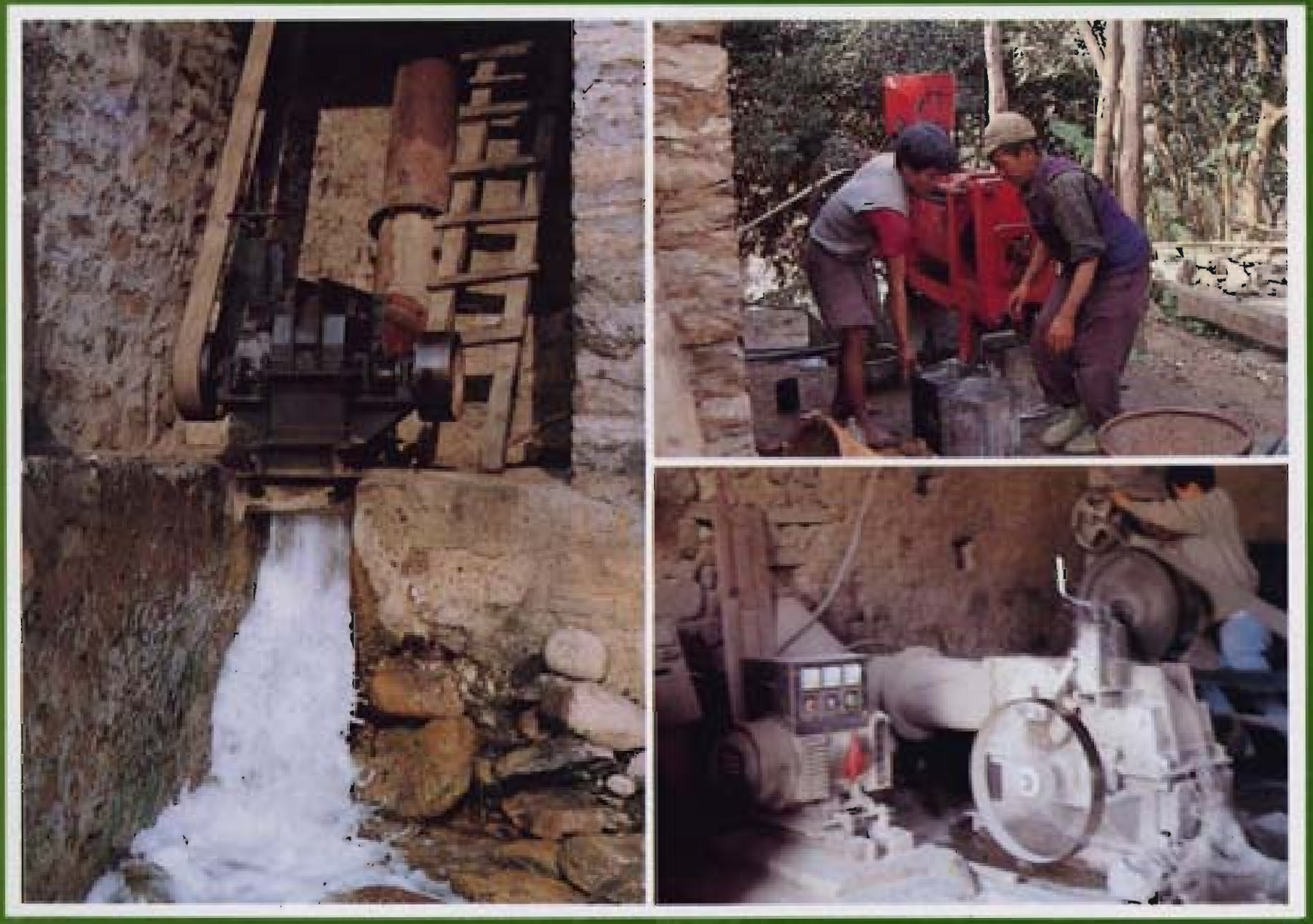

Jean-Marion Aitken

Godfrey Cromwell

Gregory Wishart

ICIMOD OCCASIONAL PAPER NO. 16

Kathmandu, NEPAL

December 1991 
No. 1 EROSION AND SEDIMENTATION PROCESSES IN THE NEPALESE HIMALAYA

Brian Carson

August 1985.

No. 2 INTEGRATED RURAL DEVELOPMENT PROJECTS IN NEPAL: A REVIEW

Bharat B. Pradhan

December 1985.

No. 3 SUSTAINING UPLAND RESOURCES: PEOPLE'S PARTICIPATION IN

WATERSHED MANAGEMENT

Anis Ahmad Dani and J. G. Campbell

July 1986.

No. 4 DECENTRALISED ENERGY PLANNING AND MANAGEMENT FOR

THE HINDU KUSH-HIMALAYA

Deepak Bajracharya

September 1986.

No. 5 GLACIAL LAKE OUTBURST FLOODS AND RISK ENGINEERING IN THE HIMALAYA

Jack D. Ives

November 1986.

No. 6 OPERATIONAL EXPERIENCES IN FOREST MANAGEMENT DEVELOPMENT

IN THE HILLS OF NEPAL

G.B.Applegate and D.A.Gilmour

January 1987.

No. 7 FORESTRY - FARMING LINKAGES IN THE MOUNTAINS

T.B.S.Mahat

March 1987.

No. 8 ROAD CONSTRUCTION IN THE NEPAL HIMALAYA:

THE EXPERIENCE FROM THE LAMOSANGU - JIRI ROAD PROJECT

Urs Schaffner

March 1987.

No. 9 MOUNTAIN ENVIRONMENTAL MANAGEMENT IN THE ARUN RIVER BASIN OF NEPAL John R. Dunsmore

December 1988.

No. 10 HILL AGRICULTURE AND THE WIDER MARKET ECONOMY:

TRANSFORMATION PROCESSES AND EXPERIENCE OF THE BAGMATI ZONE IN NEPAL

Mahesh Banskota

May 1989.

No. 11 HIGHLAND-LOWLAND INTERACTIONS IN THE GANGES-BRAHMAPUTRA RIVER BASIN: A REVIEW OF PUBLISHED LITERATURE

L.A. Bruijnzeel and C.N. Bremmer

July 1989.

No. 12 MICRO-LEVEL ENVIRONMENTAL MANAGEMENT: OBSERVATIONS ON PUBLIC AND PRIVATE RESPONSES IN KAKANI PANCHAYAT

Saroj K. Basnyet

June 1989.

No. 13 CASE STUDY ON MOUNTAIN ENVIRONMENTAL MANAGEMENT: NYEMO COUNTY (TIBET) Zhang Rongzu

August 1989.

No. 14 NATURAL RESOURCE MANAGEMENT IN THE MOUNTAIN ENVIRONMENT:

EXPERIENCES FROM THE DOON VALLEY, INDIA

Jayanta Bandyopadhyay

August 1989.

No. 15 LANDSLIDE MANAGEMENT IN THE MOUNTAIN AREAS OF CHINA

Li Tianchi

October 1990 
Mini- and Micro-Hydropower in Nepal

Jean-Marion Aitken

Godfrey Cromwell

Gregory Wishart

ICIMOD OCCASIONAL PAPER No. 16

Published by

International Centre for Integrated Mountain Development

Kathmandu, Nepal 
Copyright ${ }^{(C)} 1991$

International Centre for Integrated Mountain Development

All rights reserved

Cover photographs:
Left
The Technology: Simple and Clean
Top Right
The End Use - Oil Milling
Bottom Right : The Machinery-Generating Electricity

Published by

International Centre for Integrated Mountain Development

G.P.O. Box 3226,

Kathmandu, Nepal

ISBN 92-9115-029-0

Typesetting at ICIMOD Publications' Unit

The views and interpretations in this paper are the author's and are not attributable to the International Centre for Integrated Mountain Development (ICIMOD), and do not imply the expression of any opinion concerning the legal status of any country, territory, city or area of its authorities, or concerning the delimitation of its frontiers or boundaries. 


\section{Foreword}

Energy plays a significant role in the economic development and technological advancement of societies and, concommitant with these, it plays a crucial role in human welfare. These aspects of energy were focussed upon during the Inaugural Symposium of ICIMOD in December 1983 and in the subsequent consultations, held in the countries of the Hindu Kush-Himalayan Region, where the question of energy supply and demand ranked high on the list of urgent priorities for sustainable mountain development.

Increased energy demand has not only exerted substantial pressure on Nepal's limited forest resources but also has a negative effect on its environment and economy. Nepal has no fossil fuel of its own and all requirements have to be imported. The search for other options, such as biogas, indicates that they have limited application in the more isolated and high altitude mountain areas. Renewable options, such as wind and solar power, are not technologically ready for mass dissemination. The use of mini-and micro-hydroelectricity is, therefore, the most promising option for the remote hill communities in Nepal for the foreseeable future.

Nepal's experience in the use of mini-and micro-hydro plants (MHP) is derived partly from government programmes for rural development and partly from private and community commercial ventures. In the context of public sector enterprises, MHP were seen as a means to stimulate industrial growth, bring about social benefits, and improve communications and the well-being of people in the remote areas. The lack of productive commercial end uses has been seen as one of the main drawbacks resulting in the low profitability of these installations. Private sector installations, on the other hand, initially sought to fulfill the existing need for agroprocessing and electricity generation was added on subsequently. This resulted in better integration of the technology with the local economy and fuller utilisation of the advantages offered by micro-hydro technology.

This report has made a comprehensive study of the development of MHP in Nepal. This has been supplemented by examples from other countries. In the context of Nepal, the decentralised approach, as inherent in MHP programmes, is in line with the government policies for rural development through the decentralisation of the administration. The report has highlighted some of the principal issues to be addressed in order to ensure that MHP fulfills its crucial role in meeting the energy needs of rural communities. These issues include lack of clear-cut, overall government objectives, debate over types of subsidies, and the problems of scale.

ICIMOD is publishing this report on Mini-and Micro-hydropower in Nepal as a part of its Occasional Paper Series. There is no doubt that the knowledge and expertise acquired by ITDG from over more than a decade's experience in the development and transfer of MHP technology, for the purpose of rural development in the mountain regions of Nepal, will be useful to those involved in MHP development in the Hindu Kush-Himalayan Region and to others associated with such activities in mountain regions elsewhere. Special thanks are due to Jean-Marion Aitken, Godfrey Cromwell, and Gregory Wishart for their work in preparing this account of Nepal's experiences in the exploitation of its hydropower resources. 


\section{Preface}

Nepal has a long history of water management including a very large number of village water mills for corn grinding. The harnessing of water power on a small-scale has recently become an increasingly important aspect of rural energy supply, particularly in remote mountain areas of the country.

ICIMOD has identified mini- and micro-hydropower as an important area of interest in its sıarch for integrated approaches to the institutional, environmental, and economic development of the Himalayan Region.

ITDG has been involved for more than a decade in assisting the development and transfer of microhydro technology as a tool for rural development in the hill and mountain areas of Nepal.

This paper is a synthesis of knowledge and experience in Nepal's mini- and micro-hydro sectors. We hope that it will be an important contribution to current debates concerning the use of the resources of the Himalayan Region to promote sustainable rural development.

Ray Holland Operations Director ITDG 


\section{Table of Contents}

Preface

Foreword

Frontispiece

I. Introduction

II. The Development of Hydropower in Nepal

The Context of Hydropower in Nepal

The Role of Hydropower in the Development of Nepal's Hills

Current Energy Usage

Energy Demands

Energy Sources

The Demand for Mini- and Micro-Hydroelectricity

Factors Affecting the Use of Mini- and Micro-Hydroelectricity

The Performance of the Public and Private Sectors

Management and Organisational Aspects of the Two Sectors

Public Sector

Private Sector

Scale

Experiences from Other Countries

China

Norway

Lessons Derived from the Experiences of Other Countries

Micro-hydro as a National Development Tool

III. Issues in the Development of Hydropower Resources

The Cost of Hydropower

Scale

Local Accountability

Standardisation 24

Technological Alternatives $\quad 24$

The Comparative Cost of Micro-hydro 25

Grid Extension versus Stand-alone Installations $\quad 26$

$\begin{array}{ll}\text { Government Subsidies } & 27\end{array}$

$\begin{array}{lr}\text { The Present Situation } & 27\end{array}$

$\begin{array}{ll}\text { The Way Forward } & 28\end{array}$ 
The Performance of Government Development Plans 30

Performance of the Policy-shaping Institutions 31

Energy Efficiency

Demand Management 32

End Use Development

Identification of Potential End Uses

Research and Development $\quad 36$

$\begin{array}{ll}\text { Coordination } & 36\end{array}$

$\begin{array}{ll}\text { Coordination and Control } & 38\end{array}$

$\begin{array}{ll}\text { Public Sector } & 38\end{array}$

$\begin{array}{ll}\text { Private Sector } & 38\end{array}$

$\begin{array}{ll}\text { Impacts and Benefits } & 39\end{array}$

$\begin{array}{ll}\text { Agro-processing } & 39\end{array}$

$\begin{array}{ll}\text { Time/Labour } & 39\end{array}$

Coverage $\quad 40$

Income Generation $\quad 40$

$\begin{array}{ll}\text { Health } & 40\end{array}$

$\begin{array}{lr}\text { Electrification } & 40\end{array}$

Lighting $\quad 42$

Fuel Substitution $\quad 42$

$\begin{array}{lr}\text { Irrigation } & 43\end{array}$

Environmental Impact $\quad 43$

Economic Impact $\quad 44$

Equity $\quad 44$

IV. Constraints and Opportunities 46

$\begin{array}{ll}\text { Policy } & 46\end{array}$

$\begin{array}{ll}\text { Information } & 48\end{array}$

$\begin{array}{ll}\text { Training } & 49\end{array}$

Design $\quad 50$

Funding and Planning $\quad 50$

Installation $\quad \mathbf{5 0}$

Management $\quad 50$

Operation $\quad 51$

Maintenance 51

End Uses $\quad 51$

Roles and Opportunities $\quad 51$

$\begin{array}{ll}\text { Technology } & 52\end{array}$

Conclusion $\quad 53$

$\begin{array}{lr}\text { Bibliography } & 82\end{array}$ 
1: Electricity Prices in the Asia Pacific Region

2: The Policy Behind the Public and Private Sector and

a Comparison of Their Operational and Financial Performances 56

History and Policy: Public Sector $\quad 56$

History and Policy: Private Sector $\quad 57$

Operational Characteristics: Public Sector

Operational Characteristics: Private Sector $\quad 58$

Financial Performance: Public Sector $\quad 58$

Financial Performance: Private Sector 59

3: A Comparison of the Costs and Performances of Five Mini- and Micro-hydro Schemes 60

4: $\quad$ Procedures in the Planning, Installation, and Management of Public

and Private Installations

Public Sector

61

$\begin{array}{ll}\text { Private Sector } & 61\end{array}$

5: $\quad$ Case Studies from the Public and Private Sectors

Private Sector: The Privately-owned Yagya Rice Mill, Khaireni, Gulmi District

Private Sector: The Community-owned Ishaneshwar Sajha Sansthan Mill, Karaputar, Lamjung District

Private Sector: The Community-owned and Community-managed Purang Installation, Mustang District

Public Sector: NEA-run Jomsom Small Hydro, Mustang District

Public Sector: Local Shareholders, Salleri-Chialsa Small Hydel Project, Solukhumbu District

6: Institutions Involved in the Energy Sector

\section{TABLES}

1: $\quad$ Existing NEA-operated Grid-connected Hydroelectric Plants (1988)

2: NEA Plants Under Construction

3: Existing NEA-operated Remote Mini- and Micro-hydroelectric Plants (1988)

4: $\quad$ NEA Mini-hydroelectric Plants Planned for Future Development

5: Capital Costs of Existing NEA-operated Mini- and Micro-Hydroelectric Plants (in 1988)

6: Management Features of Public and Private Sector Projects

7: $\quad$ Factors Affecting the Choice of Rural Energy Sources

\section{FIGURES}

1: The Different Ecological Zones in Nepal - Characteristics and Energy Options

2: Public Sector Mini- and Micro-hydro Schemes: Key Institutions and Processes Involved in Their Promotion

3: Private Sector Mini- and Micro-hydro Schemes: Key Institutions and Processes Involved in Their Promotion

4: Comparative Capital Costs of Hydropower in Asian/Pacific Countries

5: An Integrated Approach to the Use of Water Resources

6: Factors Affecting the Development of the Micro-hydro Sector

7: Load Factors of NEA Mini- and Micro-hydro Projects 


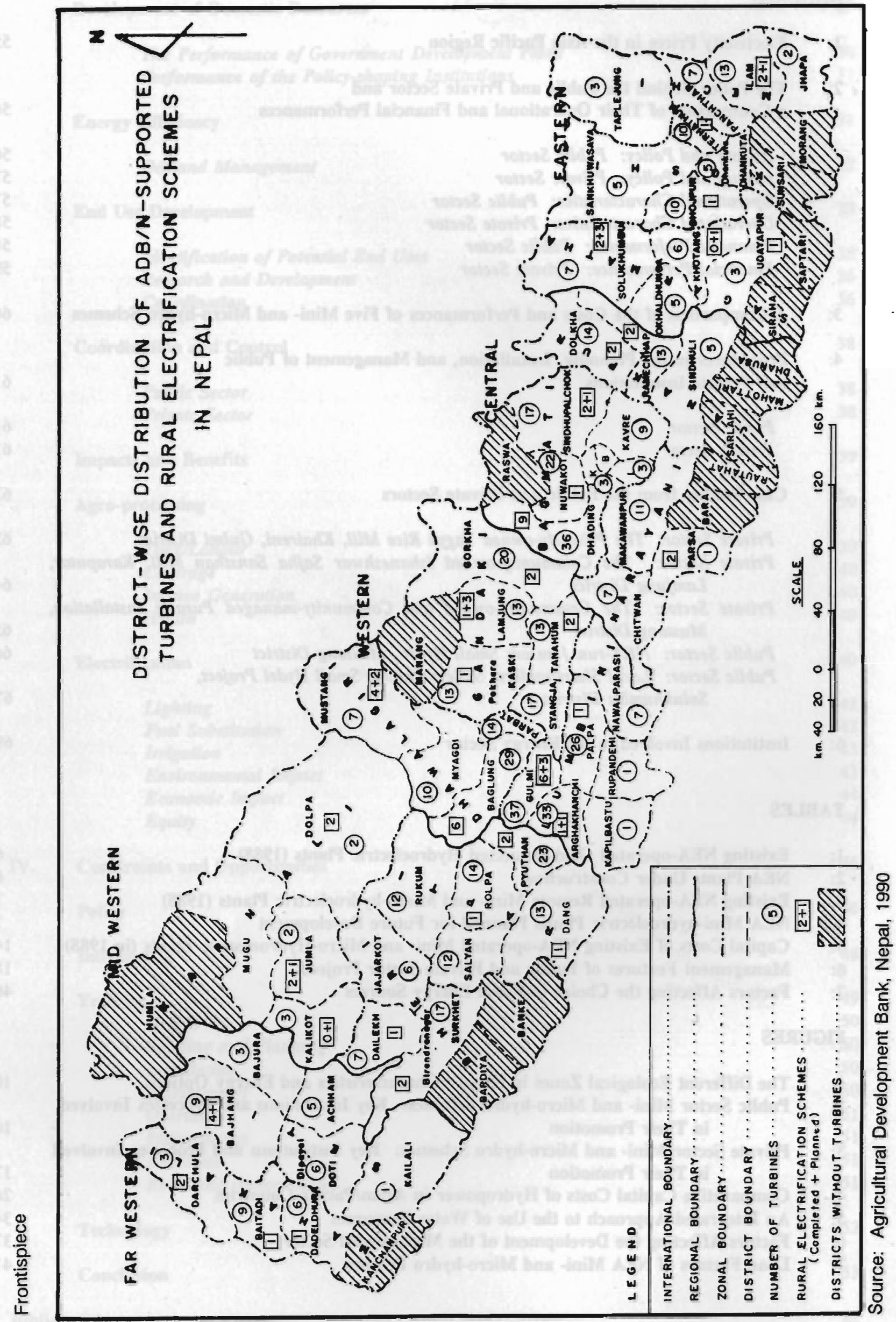

